Short Communication

\title{
Effects of natural ligands and synthetic triorganotin compounds of nuclear retinoid $X$ receptors in human MCF-7 breast cancer cell line
}

\author{
Dana Macejova, Lucia Toporova and Julius Brtko \\ Laboratory of Molecular Endocrinology, Institute of Experimental Endocrinology, BMC, Slovak Academy of Sciences, \\ Dubravska cesta 9, 84545 Bratislava, Slovakia
}

\begin{abstract}
In the present study, we analyzed in vitro effects of natural and synthetic triorganotin ligands of nuclear retinoid X receptors in human MCF-7 breast cancer cells. Our data has shown that all-trans retinoic acid significantly reduced expression of RXRalpha mRNA, Bcl2 and enhanced expression of BAX proteins. Tributyltin bromide markedly decreased mRNA level of RXRalpha and RXRbeta. Significantly reduced levels of both RXRs proteins were observed after treatment with tributyltin chloride (TBT-Cl) but not after treatment with triphenyltin chloride (TPT-Cl) for RXRbeta protein. Both RXRalpha and RXRbeta protein levels decrease was found also by combination ATRA+TBT-Cl/TPT-Cl.
\end{abstract}

Key words: Triorgatonins - Retinoid X receptor - Human breast carcinoma cells

Retinoids and rexinoids play an important role in regulation of growth, differentiation, metabolism and morphogenesis in higher vertebrates and humans. These effects are mediated through their nuclear retinoic acid receptors (RARs) and retinoid X receptors (RXRs) and their coregulators. RXRs play unique modulatory and integrative roles across multiple regulatory systems. It is well known that nuclear receptors of hormones and biologically active ligands can be affected by a number of endocrine disrupting chemicals. Organotin compounds are typical environmental contaminants used as biocides, agricultural fungicides, wood preservatives, and special paints for marine vessels and suspected endocrine-disrupting substances (Nakanishi 2008; Brtko and Dvorak 2015; Hiromori et al. 2016; Macejova 2016). A remarkable breakthrough in the field came out with the recent findings that triorganotin compounds are agonists of RXR subtypes of nuclear receptors (Fig. 1) (Delgado Filho et al. 2011; Grun 2014). Since RXRs can act predominantly as heterodimeric partners of a number of other nuclear receptors, including retinoic acid receptors (RARs), then RXR subtypes may play an important role in the modulation of many hormonal signals and regulatory pathways within the target cells (Brtko and Dvorak 2011, 2015).

Correspondence to: Dana Macejova, Institute of Experimental Endocrinology BMC, Slovak Academy of Sciences, Dubravska cesta 9, 84505 Bratislava, Slovakia

E-mail: ueenmace@savba.sk
We have recently shown that either tributyltin chloride (TBT-Cl) or triphenyltin chloride (TPT-Cl) is capable to compete for 9-cis retinoic acid (9cRA) binding sites on the RXR molecule nearly to the same degree as 9cRA (Toporova et al. 2016a). We examined the RXR-binding capability of wide range of commercially available triorganotin derivatives represented by tributyltin derivatives: $\mathrm{TBT}-\mathrm{Cl}$, tributyltin bromide (TBT-Br), tributyltin iodide (TBT-I); tributyltin hydride (TBT-H) and triphenyltin derivatives: TPT-Cl and triphenyltin hydride (TPT-H) (Sigma, Germany). We performed series of binding experiments (method described in Toporova et al. 2016), where we measured binding ability of all investigated tributyltin derivatives in following order: TBT-Cl > TBT-Br > TBT-I (Toporova et al. 2016b). Hydrides of trialkyltin- and triphenyltin derivates showed very little RXR-binding capability.

Moreover, using proteomics analyses, we have detected several proteins - the specific breast cancer biomarkers differentially expressed in MCF-7 cells after treatment with all-trans retinoic acid (ATRA) and 9cRA isomers (Flodrova et al. 2013).

Based on these data we performed several series of in vitro experiments in order to evaluate potential effects of various tributyl- and triphenyltin derivates alone and in combination with retinoic acid. The MCF-7 human breast cancer cell line were routinely cultured in Dulbecco's modified Eagle's medium (DMEM) supplemented with $10 \%$ foetal bovine se- 


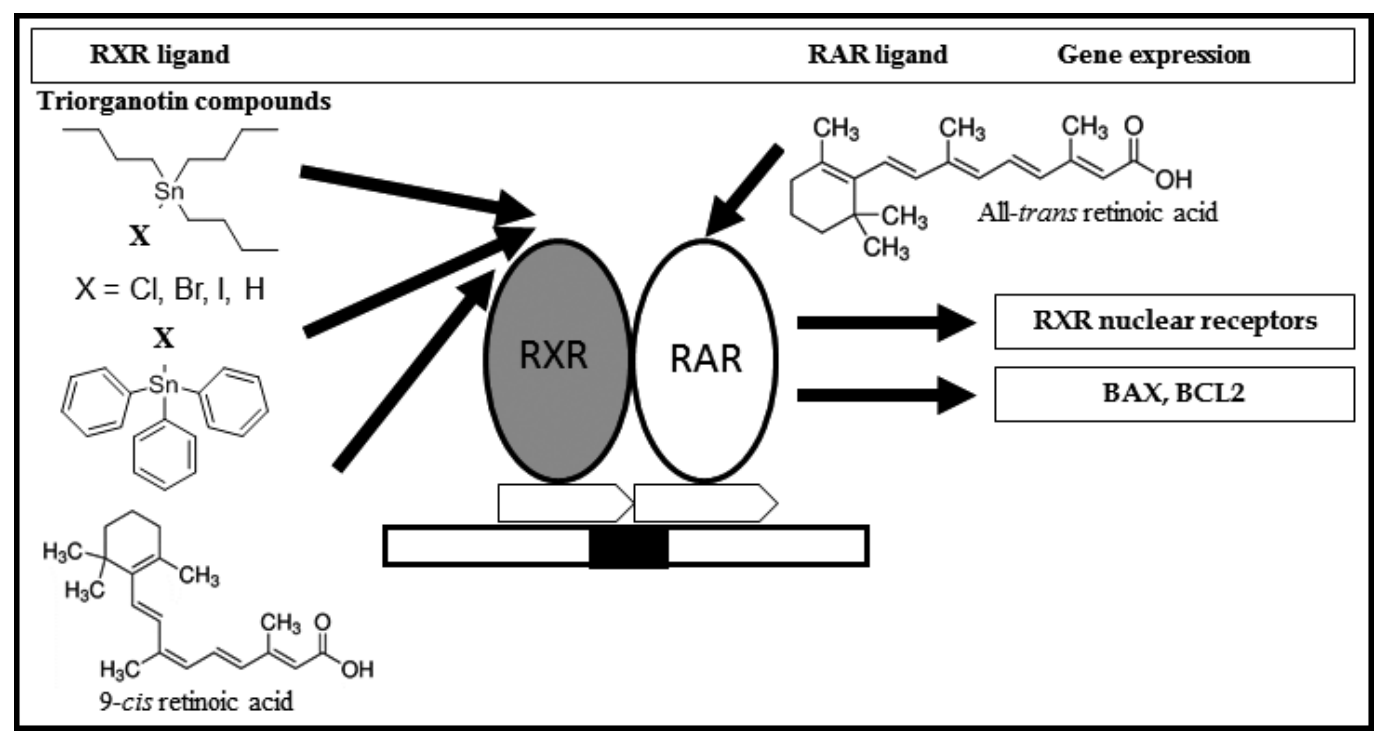

Figure 1. Effects of natural ligands and synthetic triorganotin compounds of nuclear retinoic acid receptors (RAR) and nuclear retinoid $\mathrm{X}$ receptors $(\mathrm{RXR})$.

rum (FBS), antibiotics (penicillin, streptomycin, gentamicin) and cultured in humidified atmosphere of $5 \% \mathrm{CO}_{2}$ and $95 \%$ air at $37^{\circ} \mathrm{C}$. Cells were exposed to $100 \mathrm{nM}$ concentrations of tributyltin and triphenyltin derivates (TBT-Cl, TBT-Br, TBT-I, TBT-H, and TPT-Cl, TPT-H), 9cRA (100 nM) (Sigma, Germany) and/or to ATRA (1 and $10 \mu \mathrm{M})$ for 48 hours. Stock solution of all compounds was originally dissolved in ethanol, and an equal volume of ethanol (final concentration $<0.02 \%$ ) was added to the control cells. The cells subsequently underwent both semiquantitative real-time PCR analyses of RXRalpha and RXRbeta nuclear receptors and selected genes of apoptosis ( $\mathrm{Bcl} 2$ and BAX) (method described in Hunakova et al. 2016) and Western blot analyses of proteins: RXRalpha, RXRbeta, $\mathrm{Bcl} 2$ and BAX. Nuclear proteins were isolated using
Nuclear extraction kit (Abcam, USA) according to manufacturer's instructions. Fluorescent Western blot analyses were performed using Odyssey reagents (Li-Cor, USA) and specific primary antibodies (Abcam, USA) according to manufacturers' instructions. The results were analysed by Image Studio software for Odyssey infrared imaging system (Li-Cor, USA).

On mRNA level, $10 \mu \mathrm{M}$ ATRA significantly reduced expression of RXRalpha mRNA. Combination of $10 \mu \mathrm{M}$ ATRA with 9cRA significantly reduced expression of RXRalpha and RXRbeta (Table 1) when compared to mock-treated cells. ATRA $(1 \mu \mathrm{M})$ or $9 \mathrm{cRA}(100 \mathrm{nM})$ alone did not affect expression of any RXRs.

We have already shown that $48 \mathrm{~h}$ treatment with TBT-Cl significantly reduced expression of RXRalpha and RXR-

Table 1. Real-time PCR analyses of RXR receptors

\begin{tabular}{|c|c|c|c|c|}
\hline Group & RXRalpha & RXRbeta & $\mathrm{Bcl} 2$ & BAX \\
\hline Control & $1.00 \pm 0.00$ & $1.00 \pm 0.00$ & $1.00 \pm 0.00$ & $1.00 \pm 0.00$ \\
\hline ATRA $(1 \mu \mathrm{M})$ & $1.05 \pm 0.19$ & $1.15 \pm 0.10$ & $0.33 \pm 0.04^{\star}$ & $1.37 \pm 0.06^{*}$ \\
\hline $\operatorname{ATRA}(10 \mu \mathrm{M})$ & $0.47 \pm 0.04^{*}$ & $0.94 \pm 0.20$ & $0.15 \pm 0.01^{\star}$ & $1.28 \pm 0.03^{*}$ \\
\hline 9cRA (100 nM) & $1.03 \pm 0.33$ & $0.89 \pm 0.24$ & $0.80 \pm 0.23$ & $1.18 \pm 0.34$ \\
\hline $\operatorname{ATRA}(10 \mu \mathrm{M})+9 \mathrm{cRA}(100 \mathrm{nM})$ & $0.45 \pm 0.01^{\star}$ & $0.76 \pm 0.12^{*}$ & $0.11 \pm 0.02^{*}$ & $0.98 \pm 0.06$ \\
\hline TBT-Cl (100 nM) & $0.70 \pm 0.23^{\star, \mathrm{a}}$ & $0.80 \pm 0.12^{\star, \mathrm{a}}$ & $0.56 \pm 0.20^{*}$ & $0.85 \pm 0.17$ \\
\hline TBT-Br $(100 \mathrm{nM})$ & $0.69 \pm 0.21^{*}$ & $0.82 \pm 0.13^{*}$ & $0.56 \pm 0.19^{\star}$ & $0.96 \pm 0.23$ \\
\hline ATRA $(10 \mu \mathrm{M})+$ TBT-Cl $(100 \mathrm{nM})$ & $0.49 \pm 0.15^{*}$ & $0.88 \pm 0.18$ & $0.10 \pm 0.01^{\star}$ & $1.05 \pm 0.19$ \\
\hline ATRA $(10 \mu \mathrm{M})+$ TBT-Br $(100 \mathrm{nM})$ & $0.49 \pm 0.13^{\star}$ & $0.81 \pm 0.10^{*}$ & $0.10 \pm 0.02^{\star}$ & $1.13 \pm 0.20$ \\
\hline ATRA $(10 \mu \mathrm{M})+$ TBT-I $(100 \mathrm{nM})$ & $0.53 \pm 0.14^{\star}$ & $0.84 \pm 0.05^{*}$ & $0.10 \pm 0.01^{\star}$ & $1.30 \pm 0.07^{*}$ \\
\hline ATRA $(10 \mu \mathrm{M})+$ TBT-H $(100 \mathrm{nM})$ & $0.53 \pm 0.23^{*}$ & $0.78 \pm 0.10^{*}$ & $0.10 \pm 0.03^{*}$ & $1.52 \pm 0.02^{*}$ \\
\hline
\end{tabular}

${ }^{\star} p<0.05 v s$. Control group and ATRA $(1 \mu \mathrm{M})$ group; ${ }^{a}$ results were published in Hunakova et al. (2016). 
A

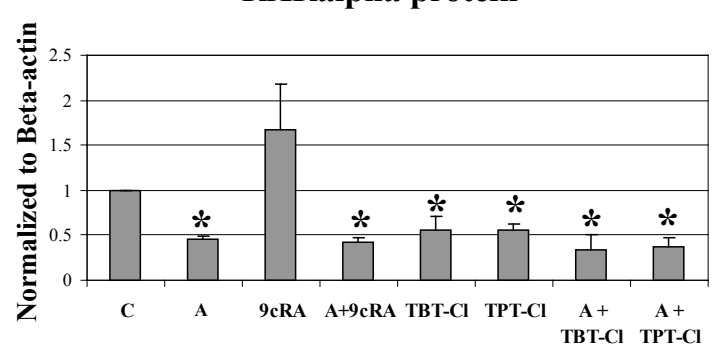

B

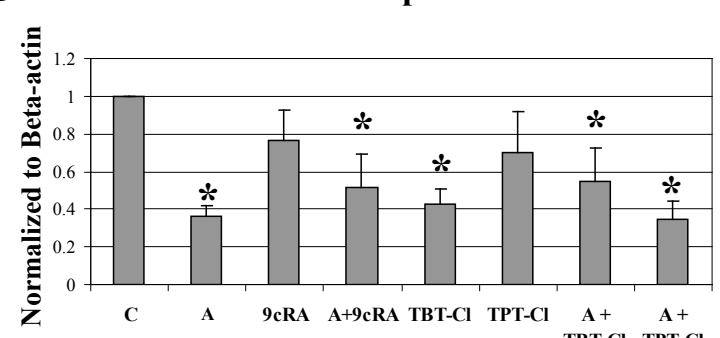

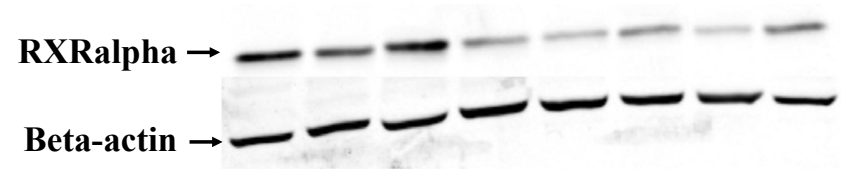

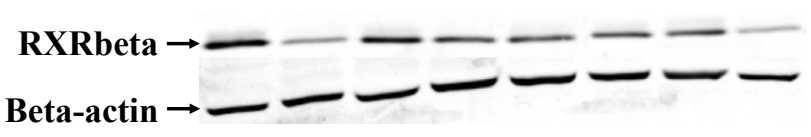

Figure 2. Western analyses of RXRalpha (A) and RXRbeta (B) receptors using Odyssey infrared imaging system and Image Studio software. Cells were treated with $1 \mu \mathrm{M}$ ATRA and/or $100 \mathrm{nM}$ 9cRA, $100 \mathrm{nM}$ TBT-Cl, $100 \mathrm{nM}$ TPT-Cl (48 hours). ${ }^{\star} p<0.05 v s$. control (C). A, ATRA.

beta mRNA (Hunakova et al. 2016). The similar significant reduction of RXRalpha and RXRbeta mRNA was observed after treatment with tributyltin bromide TBT-Br (Table 1). Combination of tributyltin derivates with $10 \mu \mathrm{M}$ ATRA significantly reduced expression of RXRalpha and RXRbeta mRNA $(p<0.05)$ when compared to mock and $1 \mu$ M ATRAtreated cells (Table 1 ), which is consistent with combination $10 \mu \mathrm{M}$ ATRA + natural RXR ligand (9cRA). However, we did not find any effects of triphenyltin derivates on rexinoid receptors on mRNA level.

Since effects on RXRs mRNA levels of ATRA + triorganotin derivate combination could be the result of concentration of $10 \mu \mathrm{M}$ ATRA in this combination, we have decided to use lower concentration of ATRA and performed protein Western blot analyses of the combination $1 \mu \mathrm{M}$ ATRA + $100 \mathrm{nM} 9 \mathrm{cRA}$ and two of the strongest RXR-binding derivates: TBT-Cl and TPT-Cl. Treatment with $1 \mu \mathrm{M}$ ATRA significantly reduced protein level of RXRalpha and RXRbeta when compared to mock treated cells (Fig. 2). $100 \mathrm{nM}$ 9cRA did not affect RXRalpha or RXRbeta at the protein level. On the other hand, the significantly reduced levels of RXRalpha and RXRbeta proteins were observed after treatment with TBT-Cl but not after treatment with TPT-Cl for RXRbeta protein. Both RXRalpha and RXRbeta protein levels decrease was found also by combination ATRA+TBT-Cl/TPT-Cl $(p$ $<0.05)$.

The discrepancy between mRNA and proteins levels of selected genes could be due to earlier onset and faster response of mRNA levels on retinoic acids when compared to protein levels after 48 hours of treatment.

Recently, we have confirmed the significant reduction of viable cells in both MCF-7 and MDA-MB-231 cell lines accompanied the increase of late apoptosis proportion/percentage in MCF-7 cells after 17 hours treatment with $200 \mathrm{nM}$ TBT-Cl and $800 \mathrm{nM}$ TPT-Cl (Hunakova et al. 2016). Since retinoic acids are involved in various processes including carcinogenesis, apoptosis and differentiation, the aim of this study was also the evaluation of effects of triorganotin derivates on $\mathrm{Bcl} 2$ and $\mathrm{BAX}$ mRNA and protein levels.

ATRA $(1 \mu \mathrm{M}$ or $10 \mu \mathrm{M})$, TBT-Cl and TBT-Br $(100 \mathrm{nM})$ significantly reduced expression of Bcl 2 mRNA when compared to mock-treated cells. However, 9cRA, TBT-I and TBT-H and triphenyltin derivates did not affect this mRNA expression (data not shown). Combination of $10 \mu \mathrm{M}$ ATRA with tributyltin derivates significantly reduced Bcl2 mRNA expression $(p<0.05)$ (Table 1$)$.

Western blot analyses showed significantly reduced $\mathrm{Bcl} 2$ protein levels after treatment with $1 \mu \mathrm{M}$ ATRA, $100 \mathrm{nM}$ $9 \mathrm{cRA}, 100 \mathrm{nM}$ TBT-Cl and $100 \mathrm{nM}$ TPT-Cl when compared to mock-treated cells $(p<0.05)$ (Table 2). Treatment with combination of ATRA+9cRA resulted in significant reduction when compared to treatment with retinoic acids alone. Moreover ATRA+TBT-Cl caused even more reduction when compared to cells treated with ATRA or TBT-Cl alone $(p<$ 0.05). Fickova et al. (2015) showed similar decreased of Bcl2

Table 2. Bcl2 and BAX protein Western blot analyses

\begin{tabular}{llc}
\hline Group & Bcl2 & BAX \\
\hline Control & $1.00 \pm 0.00$ & $1.00 \pm 0.00$ \\
ATRA $(1 \mu \mathrm{M})$ & $0.28 \pm 0.07^{\star}$ & $1.43 \pm 0.15^{*}$ \\
9cRA $(100 \mathrm{nM})$ & $0.40 \pm 0.21^{*}$ & $2.5 \pm 0.88^{*}$ \\
ATRA $(1 \mu \mathrm{M})+9 \mathrm{cRA}(100 \mathrm{nM})$ & $0.16 \pm 0.02^{\star}$ & $1.08 \pm 0.02$ \\
TBT-Cl $(100 \mathrm{nM})$ & $0.23 \pm 0.02^{*}$ & $0.67 \pm 0.01^{*}$ \\
ATRA $(10 \mu \mathrm{M})+$ TBT-Cl $(100 \mathrm{nM})$ & $0.42 \pm 0.39^{*}$ & $1.03 \pm 0.35$ \\
TPT-Cl $(100 \mathrm{nM})$ & $0.11 \pm 0.06^{*}$ & $1.34 \pm 0.62$ \\
ATRA $(10 \mu \mathrm{M})+$ TPT-Cl $(100 \mathrm{nM})$ & $0.16 \pm 0.07^{\star}$ & $1.78 \pm 0.41^{*}$ \\
\hline
\end{tabular}

${ }^{*} p<0.05$ vs. Control group. 
protein levels (TBT-Cl) on MCF-7 cells but with different experimental cell culture approach.

$1 \mu \mathrm{M}$ and $10 \mu \mathrm{M}$ ATRA $(p<0.05)$ significantly induced expression of BAX mRNA. Combination of $10 \mu \mathrm{M}$ ATRA with TBT-I and TBT-H significantly induced expression of BAX (Table 1). No effect was observed after treatment with triorganotin derivates.

Retinoic acids alone significantly increased BAX protein levels (Table 2). On the other hand TBT-Cl decreased this protein. However, since TBT-Cl significantly reduced $\mathrm{Bcl} 2$ levels, the $\mathrm{BAX} / \mathrm{Bcl} 2$ protein ratio is in favour of $\mathrm{BAX}$ protein.

Based on the results obtained in these series of experiment we might consider triorganotin chlorides (TBT-Cl and TPT$\mathrm{Cl}$ ) as the potent $\mathrm{RXR}$ ligands comparable to natural rexinoid - 9cRA. These characteristics enable to open a new research sub-area on novel organotin compounds with new leads for the development of RXR ligands with anti-tumour properties.

Acknowledgements. This work was supported by APVV-15-0372, APVV-0160-11 and VEGA 2/0171/17 grants.

\section{References}

Brtko J., Dvorak Z. (2011): Role of retinoids, rexinoids and thyroid hormone in the expression of cytochrome $\mathrm{p} 450$ enzymes. Curr. Drug. Metab. 12, 71-88 https://doi.org/10.2174/138920011795016881

Brtko J., Dvorak Z. (2015): Triorganotin compounds--ligands for „rexinoid“ inducible transcription factors: biological effects. Toxicol. Lett. 234, 50-58 https://doi.org/10.1016/j.toxlet.2015.02.009

Delgado Filho V. S., Lopes P. F., Podratz P. L., Graceli J. B. (2011): Triorganotin as a compound with potential reproductive toxicity in mammals. Braz. J. Med. Biol. Res. 44, 958-965 https://doi.org/10.1590/S0100-879X2011007500110

Fickova M., Macho L., Brtko J. (2015): A comparison of the effects of tributyltin chloride and triphenyltin chloride on cell proliferation, proapoptotic p53, Bax, and antiapoptotic Bcl-2 protein levels in human breast cancer MCF-7 cell line. Toxicol. in Vitro 29, 727-731 https://doi.org/10.1016/j.tiv.2015.02.007

Flodrova D., Benkovska D., Macejova D., Bialesova L., Bobalova J., Brtko J. (2013): Effects of retinoic acid isomers on proteomic pattern in human breast cancer MCF-7 cell line. Endocr. Regul. 47, 205-209 https://doi.org/10.4149/endo_2013_04_205

Grun F. (2014): The obesogen tributyltin. Vitam. Horm. 94, 277-325 https://doi.org/10.1016/B978-0-12-800095-3.00011-0

Hiromori Y., Yui H., Nishikawa J., Nagase H, Nakanishi T. (2016): Organotin compounds cause structure-dependent induction of progesterone in human choriocarcinoma Jar cells. J. Steroid. Biochem. Mol. Biol. 155, 190-198 https://doi.org/10.1016/j.jsbmb.2014.10.010

Hunakova L., Macejova D., Toporova L., Brtko J. (2016): Anticancer effects of tributyltin chloride and triphenyltin chloride in human breast cancer cell lines MCF-7 and MDA-MB-231. Tumour Biol. 37, 6701-6708 https://doi.org/10.1007/s13277-015-4524-6

Macejova D., Toporova L., Brtko J. (2016): The role of retinoic acid receptors and their cognate ligands in reproduction in a context of triorganotin based endocrine disrupting chemicals. Endocr. Regul. 50, 154-164 https://doi.org/10.1515/enr-2016-0018

Nakanishi T. (2008): Endocrine disruption induced by organotin compounds; organotins function as a powerful agonist for nuclear receptors rather than an aromatase inhibitor. J. Toxicol. Sci. 33, 269-276 https://doi.org/10.2131/jts.33.269

Toporova L., Macejova D., Brtko J. (2016a): Radioligand binding assay for accurate determination of nuclear retinoid X receptors: A case of triorganotin endocrine disrupting ligands. Toxicol. Lett. 254, 32-36 https://doi.org/10.1016/j.toxlet.2016.05.005

Toporova L., Macejova D., Brtko J. (2016b): Binding charasteristics of selected triorganotin compounds - nuclear retinoid X receptors agonists. Abstracts from the Bilateral Czech and Slovak Genetic Toxicology and Cancer Prevention Meeting, pp. 79-80, Telc, Czech Republic

Received: June 1, 2017

Final version accepted: August 16, 2017

First published online: August 24, 2017 